\title{
ANALYSIS OF THE SOCIAL MEDIA MARKETING: BUSINESS ENVIRONMENT AND MODERN TRENDS IN POLAND AND UKRAINE
}

\begin{abstract}
The author in the article aimed to summarize the trends in the Digital and SMM market by an analysis of the main indicators characterizing Internet and Social media users for 2014-2020 years. Theoretical part of this work was the study of the essence of the «social media marketing» concept (SMM) based on the data on the most popular social networks in Poland and Ukraine. There were analyzed the key performance indicators of the Social Media Marketing Agencies in Poland and Ukraine, such as the average cost of completed projects, personnel numbers, and characteristics of the market segment on the basis of belonging to small, medium and large businesses. A number of tools for activities in various social networks are identified, the reasons for their use, features and methods of promotion are considered.
\end{abstract}

Keywords: SMM-marketing, social media, social networks, marketing communications, sales, consumer behavior analysis.

\section{INTRODUCTION}

The current economic and social environment is characterized by a rapid increase in the number of Internet users and Social media users worldwide. Of course, each country is characterized by its own characteristics of these processes. The Internet, information technology, social networks are used for professional activities and business, leisure and social communications. Social Media Marketing (SMM) is becoming a modern effective tool for promotion and marketing, the importance of which has increased in time of Covid-19 pandemic and caused by it lockdown.

Social media is a web-based form of data communication. Social media platforms allow users to have conversations, share information and create web content. It has different forms, together with blogs, micro-blogs, wikis, social networking sites, photo-sharing sites, instant messaging, video-sharing sites, podcasts, widgets, virtual worlds, and more. Billions of people around the world use social media to share information and make connections.

SMM is creating the involvement and effective interaction of all stakeholders. The audience of social networks is characterized by a higher level of attention, interest and activity, compared to other channels of promotion, which are the characteristic to the network communication.

\footnotetext{
${ }^{1}$ Yanina Lisun, $\mathrm{PhD}$ of Economics, Associate Professor, Kyiv National University of Trade and Economics, Ukraine; e-mail: y.lisun@knute.edu.ua. ORCID: 0000-0002-5250-2809
} 
Social network users share links, news, useful information, put "likes" and actively comment on posts, which helps to increase the size of the audience of potential consumers. All this allows influencing cohabitants (users) through information and communication.

The key characteristics of SMM are targeting, interactivity, effective tools for selecting the target audience by various economic, age, educational, professional, status, psychographic, behavioral, territorial and many other criteria, relatively low price and wide range of non-standard methods of promotion. (Shtal, Dmytriiev, 2019).

The advantages of SMM promotion are: low cost, high viral effect, prospects for active development of the company. The main disadvantages of SMM are the lack of both information and analytics, which determines the demand for professional activities of relevant professionals. A characteristic feature of SMM is also control by network moderators, the need for administration and competition, the struggle for users and the formation of a stable level of brand loyalty. (W. Akram, Kumar, 2017).

On an individual level, social media allow us to communicate with our friends and relatives, gain knowledge of new things, develop your interests, and be entertained. On a professional level, we can make use of social media to expand or broaden our knowledge in a particular field and build our professional network by connecting with other professionals in our industry. At the business level, social media allows us to have a conversation with our audience, gain customer feedback, and elevate your brand (Akram, Kumar, 2017).

\section{LITERATURE REVIEW}

Possibilities and advantages of product promotion by enterprises with the help of SMM tools have been studied in works by such scientists as T.V. Shtal, H.B. Dmytriiev (Shtal, Dmytriiev, 2019), M.V. Miroshnyk, L.O. Striuk, D.O. Kopytsa (Miroshnyk, Striuk, Kopytsa, 2020), Beata Zatwarnicka-Madura (Zatwarnicka-Madura, Stecko, Mentel, 2016).

Iryna Pentina, Anthony C. Koh and T.Le Thuong pay attention to the study of the adoption of social networks marketing by SMEs by exploring the role of social influences and experience in technology acceptance (Pentina, Koh, Thuong, 2018) .

Abderlahim M. Zabadji in its scientific works the need to establish the effect of Social Media Marketing (SMM) on consumer's loyalty to the brand (Zabadji, 2019).

W. Akram and R. Kumar pointed on negative effects of social media on society, studied popular social media sites, impact of social media on medical and health, business, education, society, on kid and teens, handling influence of social media on youth and teens (Akram, Kumar, 2017). Also question about social responsibility of mass media was studied by known sociologist J. Stecko (Stecko, 2018).

Huge practical analysis was done by Simon Kemp (Kemp, Report Digital on 2014-2020 years). In this yearly reports since 2012 was collected merely all statistic of comprehensive study of digital, social and mobile use around the world, produced in partnership with We Are Social (https://datareportal.com/).

Also the author wants to thank to the job done by analytics of clutch.co - commercial project of platform of in-depth client reviews, data-driven content, and vetted market leaders.

However, further research is needed on the theory and practice of using SMM in marketing activities in the $\mathrm{B} 2 \mathrm{C}$ and $\mathrm{B} 2 \mathrm{~B}$ market. The above determined the purpose of the 
article, which is to summarize the practical indicators of the use of SMM as a modern marketing technology.

\section{AIM OF THE STUDY}

The article is aimed at researching the main characteristics of the players at the social media market in Poland and Ukraine. The research objectives are:

- an analysis of the main trends in the field of Internet users and Social media users in the world, and in particular in Poland and Ukraine;

- characteristics of the share of the social media marketing agencies projects according to business size in Poland and Ukraine;

- monitoring the structure of the social media marketing agencies according to such criteria as the minimum project size, brand agency stuff numbers;

- an analysis the popularity of the social media marketing agencies at such areas: corporate identity, brand strategy, product branding, communication (message) of the brand, naming;

- an analysis of the focus service lines of the top social media marketing agencies in Poland and Ukraine;

- an analysis of the PPC focus service lines of the top social media marketing agencies in Poland and Ukraine;

- substantiation of future trends and activities changes of the Poland and Ukraine social media marketing.

\section{RESULTS AND DISCUSSION}

According to data from the Report Global Digital Overview 2019 and 2020 of the International Telecommunication Union (ITU) the number of people using the internet has surged over the past year, with more than one million people coming online for the first time each day. In particular here are:

- 4,54 billion internet users in 2020, an increase of 152 million (3\%) versus January 2019;

- 3,80 billion social media users in 2020 , with the worldwide total growing by 316 million (9\%) since this time last year (table 1);

- 5,11 billion unique world mobile users in the 2019, up 100 million ( 2 percent) in the 2018;

- 3,26 billion people use social media on mobile devices in January 2019, with growth of 297 million new users representing a year-on-year increase of more than $10 \%$ (Report Global Digital Overview, 2020)

Internet users spend a lot time using it. Average amount of time per day using the internet via any device, in hours and minutes is 6,42 worldwide and 6,02 in Poland in 2019.

The number of Internet users worldwide for the period 2014-2020 increased by $82 \%$ (from 2484 to 4540 millions). The number of social media users worldwide more than doubled between 2014 and 2020 (from 1857 to 3800 millions) (table 1).

Social media dispersion in 2019 (territory, compared to total population) is $45 \%$ worldwide and $47 \%$ in Poland, $39 \%$ in Ukraine. Average amount of time per day using social media via any device in 2019 , in hours and minutes was 2,16 worldwide and 1,45 in Poland (Report Digital, 2019, Poland). 
Table 1. Internet users and Social media users in 2014-2019 years worldwide

\begin{tabular}{|c|c|c|c|c|c|c|c|}
\hline & $\mathbf{2 0 1 4}$ & $\mathbf{2 0 1 5}$ & $\mathbf{2 0 1 6}$ & $\mathbf{2 0 1 7}$ & $\mathbf{2 0 1 8}$ & $\mathbf{2 0 1 9}$ & $\mathbf{2 0 2 0}$ \\
\hline Internet users over time, millions & 2485 & 3,008 & 3429 & 3779 & 4021 & 4388 & 4540 \\
\hline Social media users over time, millions & 1857 & 2078 & 2307 & 2796 & 3196 & 3484 & 3800 \\
\hline
\end{tabular}

Developed based on: Report Global Digital Overview in 2014, 2015, 2016, 2017, 2018, 2019 and 2020 years (https://datareportal.com/reports).

Not only the numbers grow, but also ways in which people use the internet also are evolving quickly too, with smartphones adding ever-increasing share of our online activities. Mobile phones used for almost half the time that people spend on the internet. On average, the world's internet users spend 6 hours and 42 minutes online each day.

Despite the year-on-year drop, our online time quickly adds up. An average of more than 6,5 hours a day equates to a total of more than 100 days of online time each year for every internet user. If we extend that average across the total internet user base of almost 4.4 billion users, we find that humanity will spend a collective total of more than 1.2 billion years online in 2019 year (Report Global Digital, 2019).

Although many people's connected activities now rely on recent innovations like native mobile apps, the Web still represents «the internet» for most users around the world. Worldwide social media user numbers have grown to almost 3,5 billion at the start of 2019, with 288 million new users in the past 12 months pushing the global penetration figure to 45 percent. Many countries have shown strong growth in social media use over the past 12 months.

The process of change of Internet and Social media users behavior is influenced by such factors as:

- technical factors (level of urbanization, quality of infrastructure, availability of devices, Internet speed);

- socio-demographic factors (average age of the population of a country, the ratio of men and women, income level, employment, cultural characteristics):

- economic factors (average income, average purchase size, level of e-Commerce development).

Let's analyze the indicators for Internet users in Poland and Ukraine in 2017-2020 years (Table 2, 3).

In Poland for the period 2017-2020 years the number of Internet users increased by 2.71 million (from 27.92 to 30.63 millions). The share of Internet users in relation to the total population of Poland in 2020 year was $81 \%$.

In Poland for the period 2017-2020 years the number of active social media users increased by 4.0 million (from 15.00 to 19.00 millions). The share of active social media users, in relation to the total population of Poland, in 2020 year was 50\%.

The level of urbanization in Poland in 2020 year was $60 \%$ (table 2).

In Ukraine for the period 2017-2020 the number of Internet users increased by 2.71 million (from 21.93 to 27.46 million). The share of Internet users in relation to the total population of Ukraine in 2020 was $63 \%$. 
Table 2. The essential headline data about mobile, internet and social media use in Poland in 2017-2020 years

\begin{tabular}{|l|c|c|c|c|}
\hline & $\mathbf{2 0 1 7}$ & $\mathbf{2 0 1 8}$ & $\mathbf{2 0 1 9}$ & $\mathbf{2 0 2 0}$ \\
\hline Total population, million & 38,58 & 38,14 & 38,07 & 37,87 \\
\hline Urbanization, \% & 61 & 61 & $60 \%$ & 60 \\
\hline Internet users, million & 27,92 & 29,75 & 30,07 & 30,63 \\
\hline Penetration, \% & 72 & 78 & $79 \%$ & 81 \\
\hline Active social media users, million & 15,0 & 17,0 & 18,00 & 19,00 \\
\hline Penetration,\% & 39,0 & 45 & 47 & 50 \\
\hline
\end{tabular}

Developed based on the analytics "Report Digital"of datareportal.com on 2017-2020 years in Poland and Ukraine.

In Ukraine for the period 2017-2020 the number of active social media users increased by 4.0 million (from 16.17 to 19.00 million). The share of active social media users, in relation to the total population of Ukraine, in 2020 was $43 \%$.

The level of urbanization in Ukraine in 2020 was $43 \%$ (Table 3).

Table 3. The essential headline data about mobile, internet and social media use in Ukraine in 2017-2020 years

\begin{tabular}{|l|c|c|c|c|}
\hline & $\mathbf{2 0 1 7}$ & $\mathbf{2 0 1 8}$ & $\mathbf{2 0 1 9}$ & $\mathbf{2 0 2 0}$ \\
\hline Total population, million & 44,51 & 44,12 & 43,9 & 43,86 \\
\hline Urbanization, \% & 70 & 70 & 69 & 69 \\
\hline Internet users, million & 21,93 & 25,59 & 40,91 & 27,46 \\
\hline penetration & 49 & 58 & 93 & 63 \\
\hline Active social media users, million & 16,17 & 13,00 & 17,00 & 19,00 \\
\hline compared to total population & 36 & 29 & 39 & 43 \\
\hline
\end{tabular}

Developed based on the analytics "Report Digital" of datareportal.com on 2017-2020 years in Ukraine.

According to the results of the analysis "Social media users behavior in 2019" the amount of time that people spend on social media has increased again in 2019, albeit very slightly. Global Web Index reports that the average social media user now spends 2 hours and 16 minutes each day on social platforms, which equates to roughly one-third of their total internet time, and one-seventh of their hours awake. We get a combined total of almost 330 million years of human time spent on social platforms during 2019 year (Report Global Digital Overview, 2020).

Facebook's advertising audience did lose 10 million users aged 13 to 17 in the last 3 months of 2018, although it made up for this loss with an equivalent gain in the number of users over the age of 55 (Report Global Digital Overview, 2019)

The median number of posts 'liked' by the typical Facebook user has fallen by 10 percent in the past 6 months, and now stands at 9 per month.

These findings reinforce the fact that Facebook users aren't going to Facebook just to see advertisements. People's primary motivations for using Facebook remain of the original aim with what this platform was built - staying in touch with friends and family, and these activities accounts for the lion's share of the time that people spend on the platform. 
If it necessary to succeed with Facebook marketing, you need to give people more of what they want, and less of brand's corporate propaganda (Kemp, Report Global Digital Overview, 2019).

The above global trends are also characteristic of Poland and Ukraine.

Number of people that Facebook reports can be reached with adverts did lose 1 million users in Poland in 2020 and number of Facebook users in 2020 is 16 million. A similar rate is in Ukraine - 13 million (Table 4).

Table 4. Facebook Audience overview in Poland and Ukraine in 2019-2020 years

\begin{tabular}{|l|c|c|c|c|c|c|}
\hline & \multicolumn{3}{|c|}{ Poland } & \multicolumn{3}{c|}{ Ukraine } \\
\cline { 2 - 7 } & $\mathbf{2 0 1 8}$ & $\mathbf{2 0 1 9}$ & $\mathbf{2 0 2 0}$ & $\mathbf{2 0 1 8}$ & $\mathbf{2 0 1 9}$ & $\mathbf{2 0 2 0}$ \\
\hline $\begin{array}{l}\text { Number of people that Facebook reports can be } \\
\text { reached with adverts on Facebook, million }\end{array}$ & 17,0 & 17,00 & 16,00 & 13,00 & 13,0 & 13,0 \\
\hline $\begin{array}{l}\text { Facebook's reported advertising reach compared to } \\
\text { total population aged 13+, \% }\end{array}$ & - & 51 & 49 & - & 34 & 34 \\
\hline $\begin{array}{l}\text { Percentage of its audience that Facebook reports is } \\
\text { female, \% }\end{array}$ & 51 & 52 & 53,4 & 57 & 59 & 60,4 \\
\hline $\begin{array}{l}\text { Percentage of its audience that Facebook reports is } \\
\text { male, \% }\end{array}$ & 49 & 48 & 46,6 & 43 & 41 & 39,6 \\
\hline
\end{tabular}

Developed based on the analytics "Report Digital" of datareportal.com on 2018-2020 years in Poland and Ukraine.

However, comparisons to total population are less representative when it comes to social media, because most platforms prohibit children use. As a result the dates are also include analysis of what we're terming «eligible penetration»-i.e. social media use amongst people aged 13 and above.

Facebook's reported advertising reach compared to total population aged more than 13 years old is $49 \%$ in Poland in 2020 and $34 \%$ at the same period in Ukraine.

Female Facebook's audience is more than male one. Thus in 2020, percentage of audience that Facebook reports as female is $53,4 \%$ in Poland and 60,4\% in Ukraine (table 4).

Top topics for posts that are of most interest to Facebook users:

- master classes (teaching materials, photo and video lessons and practical recommendations);

- posts that contain information about new products, promotions and "behind-thescenes" life of the enterprise;

- informative posts (publications on one of the aspects of the product that form a better understanding of the product and bring it closer to purchase);

- general thematic posts;

- user feedback when a potential customer chooses a new product.

Instagram. It is indicated that Instagram will be a top choice for brands in 2019-2020. Instagram's advertising audience is 895 million active users around the world (Report Global Digital Overview, 2020).

However, this figure does not include user numbers for some countries that have sizeable Instagram audiences, but which are not available to advertisers as targeting locations (for example Iran). 
Instagram's user base may be less than half the size of Facebook's, but Instagram has added more than twice as many new users as Facebook in the past three months in 2020 (Report Global Digital Overview, 2020).

Instagram's growing popularity amongst marketers isn't just down to a growing user base, either; the platform also boasts a well-balanced audience profile. Globally, Instagram users are split roughly 50:50 between women and men, and - while the average age still skews younger than Facebook - Instagram has a higher incidence of users in the 18 to 34 year-old age bracket than Facebook does (albeit with a smaller total number of users in that age range).

Total Instagram's advertising audience is 894,9 million, among them according to age around the world: 13-17 years old - 57,0 million; 18-24 years old -280,4 million; 25-34 years old $-290,4$ million; 35-44 years old -142,2 million; 45-54 years old -73,1 million; 55-64 years old -32,0 million; more than 65 years old $-19,8$ million

The analysis showed that the total number of Instagram users in Poland increased in 2018-2020 from 5.4 to 7.3 million. The share of users over 13 in 2020 was $22 \%$. The share of Instagram users compared to the total population in Poland in 2020 is $19.28 \%$. The share of female population among Instagram users in 2020 was $58.3 \%$ (Table 5).

Table 5. Instagram Audience overview in Poland and Ukraine in 2019-2020 years

\begin{tabular}{|l|c|c|c|c|c|c|}
\hline & \multicolumn{3}{|c|}{ Poland } & \multicolumn{3}{c|}{ Ukraine } \\
\cline { 2 - 8 } & $\mathbf{2 0 1 8}$ & $\mathbf{2 0 1 9}$ & $\mathbf{2 0 2 0}$ & $\mathbf{2 0 1 8}$ & $\mathbf{2 0 1 9}$ & $\mathbf{2 0 2 0}$ \\
\hline $\begin{array}{l}\text { Number of people that Instagram reports can be } \\
\text { reached with adverts on Instagram, million }\end{array}$ & 5,4 & 6,8 & 7,3 & 7,2 & 10,0 & 11,0 \\
\hline $\begin{array}{l}\text { Instagram's reported advertising reach compared to } \\
\text { total population aged 13+, \% }\end{array}$ & - & 21 & 22 & 16 & 27 & 29 \\
\hline $\begin{array}{l}\text { Percentage of its audience that Instagram reports is } \\
\text { female, \% }\end{array}$ & 58 & 58 & 58,3 & 61 & 60 & 60,2 \\
\hline $\begin{array}{l}\text { Percentage of its audience that Instagram reports is } \\
\text { male, \% }\end{array}$ & 42 & 42 & 41,7 & 39 & 40 & 39,8 \\
\hline
\end{tabular}

Developed based on: the analytics "Report Digital" of datareportal.com on 2018-2020 years in Poland and Ukraine.

Regarding Instagram users in Ukraine, we have slightly higher rates. The analysis showed that the total number of Instagram users in Ukraine increased in 2018-2020 from 7.2 to 11.0 million. The share of Instagram users compared to the total population in Ukraine in 2020 is $25.07 \%$. In Ukraine, the share of Instagram users over the age of 13 in 2020 was $29 \%$. The share of women among Instagram users in 2020 was $60.2 \%$.

Twitter. 2018 was less favourable to Twitter, who reported declines in global active users in their two past earnings announcements. This downward trend is clearly visible in the platform's advertising audience numbers too, which indicate that Twitter's total addressable audience has fallen.

Twitter's advertising audience also skews significantly towards men, with the platform reporting that almost two-thirds of its addressable audience is male.

Twitter has grown to become a platform of choice for various influential figures around the world, from presidents and prime ministers, to some of the world's top journalists. Crucially though, observers do not need to have a Twitter account to access all of the content 
that these people post to the platform, and this is where some broader data provide a very different story of Twitter's success compared to its earnings announcements.

While the number of 'registered' users engaging with the platform appears to be falling, overall visitor traffic to Twitter.com has actually been increasing over recent months. Similar Web's latest data suggest that Twitter.com attracted more than 670 million unique visitors in December 2018 (Report Global Digital Overview, 2018).

These figures suggest that total visitors to Twitter.com are considerably more than double the platform's total addressable advertising audience. These 670 million visitors also spend an average of more than nine minutes on the site each visit, so it's clear that they're not simply stopping in to read one or two tweets.

Interpreting these numbers, it appears that Twitter's primary problem isn't necessarily the appeal of its platform, but rather its business model. Crucially, because people can access much of Twitter's value without needing to log in, the company's primary revenue source (ad placements targeting logged-in users) appears to be out of sync with the company's primary asset (hundreds of millions of visitors, regardless of whether they're logged in).

This makes Twitter a highly attractive target for a media company who can make better sense of the potential value residing in these non-logged-in visitors.

Let's analyze in more detail the indicators of the portrait of Twitter users in Poland and Ukraine.

The analysis showed that the total number of Twitter users in Poland increased in 2019-2020 from 0.934 to 1.25 million. The share of users over 13 in 2020 was $3.8 \%$. The share of Twitter users compared to the total population of Poland in 2020 is $1.7 \%$. The share of male population among Twitter users in 2020 was $65.7 \%$ (Table 6).

Table 6. Twitter Audience overview in Poland and Ukraine in 2019-2020 years

\begin{tabular}{|l|c|c|c|c|}
\hline & \multicolumn{2}{|c|}{ Poland } & \multicolumn{2}{c|}{ Ukraine } \\
\cline { 2 - 5 } & $\mathbf{2 0 1 9}$ & $\mathbf{2 0 2 0}$ & $\mathbf{2 0 1 9}$ & $\mathbf{2 0 2 0}$ \\
\hline $\begin{array}{l}\text { Number of people that Twitter reports can be reached with adverts } \\
\text { on Twitter, million }\end{array}$ & 0,934 & 1,25 & 0,575 & 0,674 \\
\hline $\begin{array}{l}\text { Twitter's reported advertising reach compared to total population } \\
\text { aged 13+, \% }\end{array}$ & 2,8 & 3,8 & 1,5 & 1,8 \\
\hline Percentage of its audience that Twitter reports is female, \% & 32 & 34,3 & 27,0 & 30,1 \\
\hline Percentage of its audience that Twitter reports is male, \% & 68 & 65,7 & 73,0 & 69,9 \\
\hline
\end{tabular}

Developed based on: the analytics "Report Digital" of datareportal.com on 2019-2020 years in Poland and Ukraine.

Regarding Twitter users in Ukraine, we have slightly different indicators. The analysis showed that the total number of Twitter users in Ukraine increased in 2019-2020 years from 0.575 to 0.674 million. The share of Instagram users compared to the total population in Ukraine in 2020 is $1.53 \%$. In Ukraine, the share of Twitter users over the age of 13 in 2020 was $1.8 \%$, with the major share of the male population - in 2020 it was $69.9 \%$.

LinkedIn. The world's favorite professional social network LinkedIn delivered strong results in advertising.

It's important to note that LinkedIn's advertising audience numbers are based on total registered users, and not the monthly active users reported in other platform's tools. 
However, the company's latest data show that advertisers can now reach more than 600 million users around the world on LinkedIn, which tells a compelling story for brands hoping to connect with working professionals across the globe.

For LinkedIn by eligible penetration it is noted that we're using adults aged $18+$ for LinkedIn's eligible audience, rather than the 13+ we've used for the other platforms.

The analysis showed that the total number of LinkedIn users in Poland increased in 2019-2020 years from 3.3 to 3.7 million. The share of users over 18 in Poland was $12 \%$. The share of LinkedIn users, compared to the total population in Poland in 2020 year is $9.77 \%$, while the share of male population in this number was $53.3 \%$ (Table 7).

Table 7. Linkedin Audience overview in Poland and Ukraine in 2019-2020 years

\begin{tabular}{|l|c|c|c|c|}
\hline & \multicolumn{2}{|c|}{ Poland } & \multicolumn{2}{c|}{ Ukraine } \\
\cline { 4 - 6 } & $\mathbf{2 0 1 9}$ & $\mathbf{2 0 2 0}$ & $\mathbf{2 0 1 9}$ & $\mathbf{2 0 2 0}$ \\
\hline $\begin{array}{l}\text { Number of people that LinkedIn reports can be reached with adverts } \\
\text { on LinkedIn, million }\end{array}$ & 3,3 & 3,7 & 2,5 & 2,9 \\
\hline $\begin{array}{l}\text { LinkedIn's reported advertising reach compared to total population } \\
\text { aged 18+, \% }\end{array}$ & 11 & 12 & 0,7 & 1,6 \\
\hline Percentage of its audience that Linkedin reports is female, \% & 48 & 46,7 & 47 & 45,8 \\
\hline Percentage of its audience that Linkedin reports is male, \% & 52 & 53,3 & 53 & 54,2 \\
\hline
\end{tabular}

Developed based on: the analytics "Report Digital" of datareportal.com on 2019-2020 years in Poland and Ukraine.

Regarding LinkedIn users in Ukraine, we have slightly different indicators. The analysis showed that the total number of LinkedIn users in Ukraine increased in 2019-2020 years from 2.5 to 2.9 million. The share of LinkedIn users compared to the total population in Ukraine in 2020 is $6.61 \%$. In Ukraine, the share of LinkedIn users over the age of 18 in 2020 was $1.6 \%$. The share of the male population among LinkedIn users in Ukraine in 2020 was $54.2 \%$ (Table 7).

Snapchat. Snapchat's latest numbers tell an even more worrying story than Twitter's.

Snapchat's total addressable audience sits at 306.5 million at the start of 2019, down more than 10 percent since October (note that this number is based on the figures published by Snapchat itself, in the platform's own advertising tools).

While it's unclear whether the two numbers are correlated, it's worth noting that the drop of 41 million users in Snapchat's advertising audience over the past three months closely aligns to Instagram's growth of 38 million users during the same time period (Report Global Digital Overview, 2019).

Furthermore, despite the platform's existing female audience skew, Snapchat is losing male users faster than its losing women. However, Snapchat remains an important part of the social mix in a number of countries around the world, and - despite losing ground in these countries too - Snapchat still boasts a sizeable share of social media users in many countries across the Middle East.

The platform has consistently appeared to focus on younger users - particularly those in the 13 to 24 year-old age bracket. However, people in these age groups tend to be more fickle in their social media behaviors, and while this targeted approach may have served 
Snapchat well in previous years, the platform seems to be struggling to maintain its appeal amongst its core audiences.

Crucially, Instagram now boasts almost twice as many users as Snapchat in the same age bracket - and Instagram's numbers are still growing. Furthermore, unlike Twitter, there's little evidence in other data to hint at a remedy for Snapchat's ails (Report Global Digital Overview, 2019).

The analysis showed that the total number of Snapchat users in Poland increased in 2019-2020 from 3.8 to 4.0 million. The share of users over 13 in 2020 was $12 \%$. The share of Snapchat users, compared to the total population in Poland in 2020 is $10.56 \%$. The share of female population predominates among Snapchat users - in 2020 it was 57.6\% (Report Digital, 2019, Poland, Report Digital, 2020, Poland).

Let's analyze the Top 15 Social Media Marketing Agencies in Poland and Ukraine (Table 8, 9).

Table 8. Top 15 Social Media Marketing Agencies in Poland (Aug. 2020)

\begin{tabular}{|c|l|r|l|}
\hline Rank & \multicolumn{1}{|c|}{ Agencies Name } & \multicolumn{1}{c|}{$\begin{array}{c}\text { Location, } \\
\text { Founded }\end{array}$} & \multicolumn{1}{c|}{ Agencies Slogan } \\
\hline 1 & Ladder.io & Wroclaw, 2014 & $\begin{array}{l}\text { Reach Your Growth Goals. World-Class } \\
\text { Marketing }\end{array}$ \\
\hline 2 & MTA Digital & Poznań, 2014 & Digital \& Performance Marketing Team \\
\hline 3 & $\begin{array}{l}\text { FROGRIOT - digital, } \\
\text { studio }\end{array}$ & Poland, 2012 & Softwear experts - we make things happen \\
\hline 4 & Quick SEO Help & Warszaw, 2014 & Connecting customers to your Brands \\
\hline 5 & Skalski Growth & Krakow, 2014 & Growth Marketing Team for Turbulent Times \\
\hline 6 & Zest Creations & Warsaw, 2012 & In ROI we trust \\
\hline 7 & $\begin{array}{l}\text { Biuro Podrozy } \\
\text { Reklamy }\end{array}$ & Warsaw, 2003 & INTERNET EXPLORERS \\
\hline 8 & MU Interactive & Warsaw, 2011 & We Animate Ideas \\
\hline 9 & NUEKO Digital & Imielin, 2014 & We help grow your business online \\
\hline 10 & Urest & Warsaw, 2019 & $\begin{array}{l}\text { Digital Marketing solutions for } \\
\text { small\&medium sized }\end{array}$ \\
\hline 11 & x100.digital & Warsaw & We generate x-income in your business \\
\hline 12 & Bluerank & Lodz, 2005 & Success can be optimized! \\
\hline 13 & Strategiczni.pl & Wrocław, 2017 & Data driven, analytical SEO consultants \\
\hline 14 & Tribe47 & Warsaw, 2016 & Your online revenue generating partner \\
\hline 15 & 9BITS & Warsaw, 2009 & $\begin{array}{l}\text { eCommerce Agency, Web Development, } \\
\text { Mobile Apps }\end{array}$ \\
\hline
\end{tabular}

Developed based on: the analytics of clutch.co

Among presented SMM Agencies in Poland most of them are located at major Polish cities - Wroclaw, Poznań, Krakow, Warsaw, Imielin, Lodz. All of them are rather young companies - the average duration of operation in the market 5,5 years.

The table 8 is presenting slogans of the SMM Agencies in Poland, which deal with rational motive of the services quality and includes such keywords related rational motives of quality and income (price/quality):

- «reach», «growth», «goals ideas», «grow your business», «income in your business»; 
- «team experts», «growth marketing team», «analytical SEO consultants», «generating partner»;

- «connecting customers», «brands digital marketing solutions», «success can be optimized»

- «digital», «marketing», «e-Commerce agency», «web development»

The professionalism of the team ensures high quality services.

Table 9. Top 15 Social Media Marketing Agencies in Ukraine (Aug. 2020)

\begin{tabular}{|c|l|c|l|}
\hline Rank & \multicolumn{1}{|c|}{ Agencies Name } & $\begin{array}{c}\text { Location, } \\
\text { Founded }\end{array}$ & \multicolumn{1}{c|}{ Agencies Slogan } \\
\hline 1 & AdTribe & Kyiv, 2018 & $\begin{array}{l}\text { Scaling eCommerce businesses with Facebook } \\
\text { Ads! }\end{array}$ \\
\hline 2 & Respect.Studio & Lviv, 2016 & Alternative Digital Marketing Solutions for B2B \\
\hline 3 & Livepage & Dnipro, 2011 & $\begin{array}{l}\text { Design \& Digital Marketing for Local SMB, } \\
\text { e-Commerce }\end{array}$ \\
\hline 4 & 711media & Lviv, 2002 & Digital Marketing Agency \\
\hline 5 & UAATEAM & Kharkiv, 2014 & We help businesses to grow online \\
\hline 6 & WiserBrand & Kharkiv, 2015 & e-Commerce focused Company \\
\hline 7 & NOWEDO & Kiev, 2017 & NOWEDO \\
\hline 8 & Mobihunter & Kiev, 2015 & Performance Marketing Agency \\
\hline 9 & Kosmiqs LLC & Odessa, & Your reliable partner in the world of advertising \\
\hline 10 & Areanda & Kharkiv, 2011 & Outsourced inbound marketing services \\
\hline 11 & $\begin{array}{l}\text { Upturn Digital } \\
\text { Agency }\end{array}$ & Kyiv, & We help grow your business \\
\hline 12 & MixDigital & Kyiv, 2011 & Media \& Performance advertising agency \\
\hline 13 & Polimentor & Ukraine, 2010 & $\begin{array}{l}\text { We are Google Partner Internet-marketing } \\
\text { company }\end{array}$ \\
\hline 14 & $\begin{array}{l}\text { Devenup Health, } \\
\text { LLC }\end{array}$ & Chernihiv, & $\begin{array}{l}\text { Healthcare SEO and brand promotion using } \\
\text { MRank }\end{array}$ \\
\hline 15 & ITForce & Kharkiv, 2015 & $\begin{array}{l}\text { Digital Marketing Agency - Premier Google } \\
\text { Partner }\end{array}$ \\
\hline
\end{tabular}

Developed based on: the analytics of clutch.co

The table 9 is represented slogans of the SMM Agencies in Ukraine, which deal with rational motive of the services quality and includes such keywords related rational motives of quality and partnership (help, solutions, partner, healthcare):

- «scaling e-Commerce businesses», «alternative solutions», «outsourced services»

- «help businesses to grow online», «help grow your business»;

- «reliable partner», «premier Google partner», «healthcare SEO».

Among presented SMM Agencies they are located at major Ukrainian cities, all of them administrative centers - Kyiv, Lviv, Dnipro, Kharkiv, Odessa, Chernihiv. All of them are young companies - the average duration of operation in the market is 6,15 years.

These agencies are implementing projects in small business $(<\$ 10 \mathrm{M})$, midmarket (\$10M - \$1B), big enterprises (>\$1B) (Fig. 1, 2). 


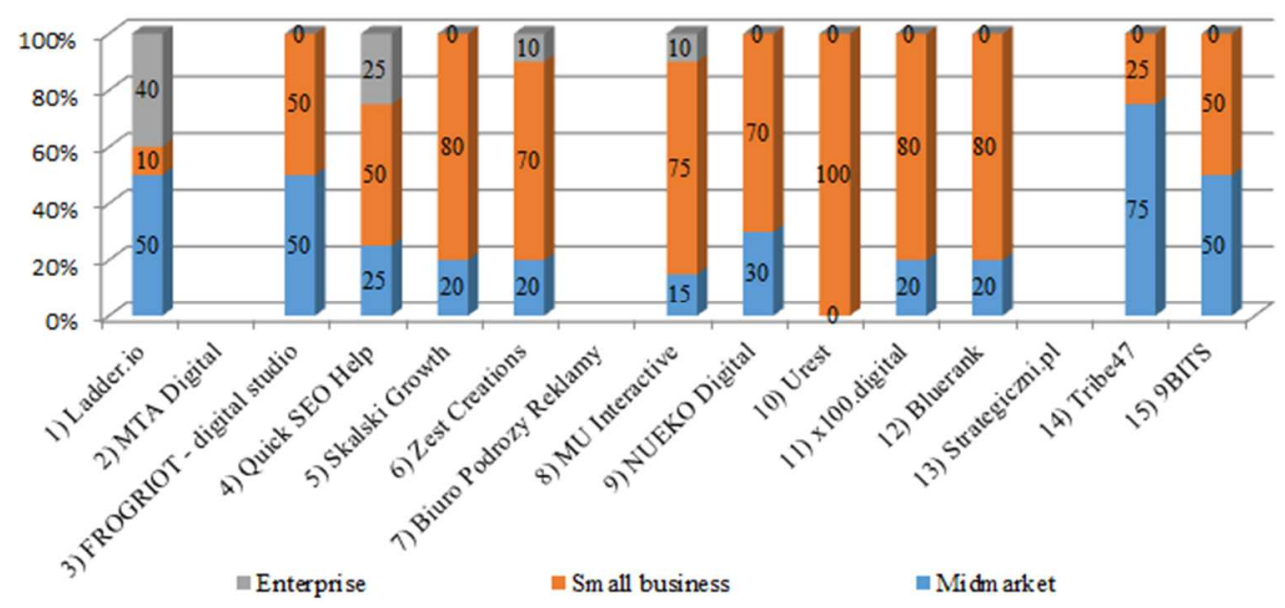

Fig. 1. Projects characteristics implemented by the leaders of the Social Media Marketing Agencies according to served business size in Poland (Aug. 2020)

Created by the authors based on the analytics of clutch.co

Among the 15 Poland top SMM Agencies, 12 agencies (80,0\%) work for the small business and midmarket. The share of the serviced companies by the relevant agencies is $15-75 \%$ for midmarket and $25-100 \%$ for small business. Four agencies $(26,67 \%)$ work for the big business (big enterprises, companies). The share of the serviced companies by the relevant agencies is $10-40 \%$.

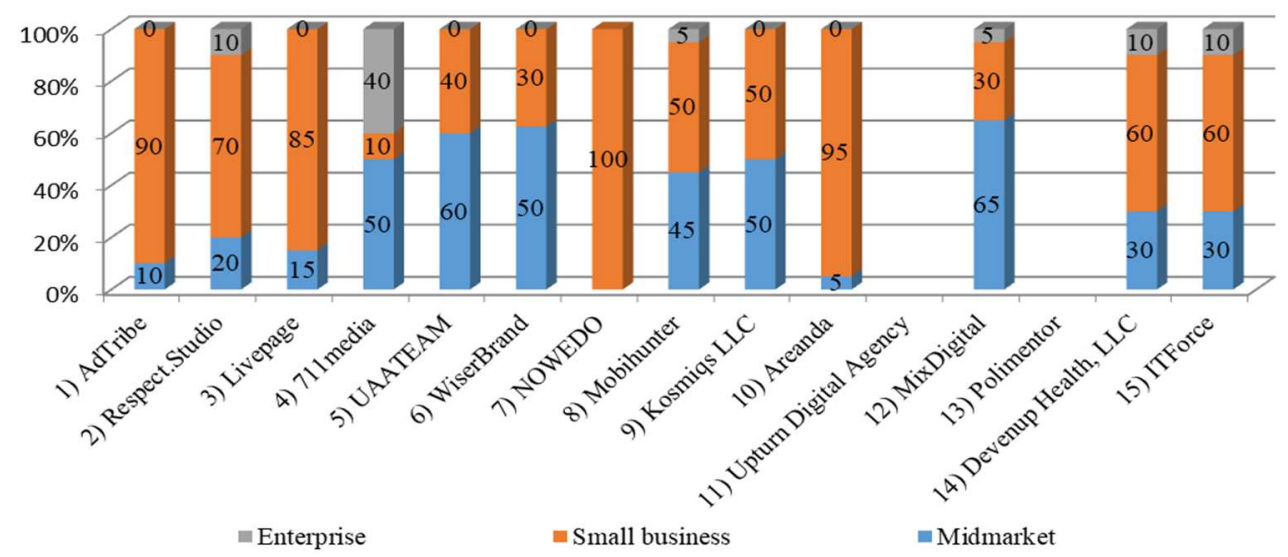

Fig. 2. Projects characteristics implemented by the leaders of the Social Media Marketing Agencies according to served business size in Ukraine (Aug. 2020)

Source: Created by the author based on the analytics of clutch.co

The same situation is in Ukraine, among the 15 top SMM Agencies, 12 agencies $(80,0 \%)$ work for the small business with the share of the serviced companies by the relevant agencies $10-60 \%, 13$ agencies $(86,67 \%)$ work for the midmarket with the share of the 
serviced companies by the relevant agencies 30-100\% and 6 agencies (40,0\%) work for the big business (big enterprises, companies). The share of the serviced companies by the relevant agencies is $5-40 \%$.

There is no available information about some SMM agencies: in Poland - «MTA Digital», «Biuro Podrozy Reklamy», «Strategiczni.pl» (Fig. 1); in Ukraine - «Upturn Digital Agency», «Polimentor» (Fig. 2).

The vast majority of SMM agencies in Poland and Ukraine implement projects with budget of $\$ 1,000$ and more. There are a lot of projects in Poland what have budget $\$ 5,000$ and more.

Medium budget projects $(\$ 10,000$ and more) have only some of the top SMM agencies in Poland (Table 10). The same situation is with big projects $(\$ 25,000$ and more; 50,000 and more). Only some of the top SMM agencies in Ukraine realize such projects.

Table 10. Top 15 Social Media Marketing Agencies in Poland and Ukraine according to the project size (Aug. 2020)

\begin{tabular}{|c|c|c|}
\hline $\begin{array}{c}\text { Project cost, } \\
\$\end{array}$ & Poland & Ukraine \\
\hline $1,000+$ & $\begin{array}{l}\text { «Quick SEO Help», «Skalski } \\
\text { Growth», «Zest Creations», «MU } \\
\text { Interactive», «NUEKO Digital», } \\
\text { «Urest», «Strategiczni.pl» }\end{array}$ & $\begin{array}{l}\text { «AdTribe», «Respect.Studio», «Livepage», } \\
\text { «UAATEAM», «Mobihunter», «Kosmiqs } \\
\text { LLC», «Areanda», «Upturn Digital } \\
\text { Agency», «MixDigital», «Polimentor», } \\
\text { «ITForce» }\end{array}$ \\
\hline $5,000+$ & $\begin{array}{c}\text { «FROGRIOT - digital studio», } \\
\text { «Biuro Podrozy Reklamy», } \\
\text { «Bluerank», «Tribe47», «9BITS» }\end{array}$ & «Devenup Health, LLC» \\
\hline $10,000+$ & «MTA Digital», «x100.digital» & - \\
\hline $25,000+$ & - & «NOWEDO» \\
\hline $50,000+$ & - & «711media», «WiserBrand» \\
\hline Undisclosed & «Ladder.io» & - \\
\hline
\end{tabular}

Created by author according to Top Poland Social Media Consultants (Dec. 2020).

The basic focuses service lines of the top 15 SMM Agencies in Poland and Ukraine are: marketing strategy, digital strategy, search engine optimization (CEO), social media marketing (SMM), conversion optimization, pay per click (PPC), mobile and app marketing, content marketing (Table 11).

The most popular service lines among SMM agencies in Poland are: SMM (100\%); Digital Strategy, Search Engine Optimization, Pay Per Click (60\%). The most popular service lines among SMM agencies in Ukraine are: SMM (100\% among of the all 15 agencies); Search Engine Optimization, Pay Per Click (66,7\% among of the all 15 agencies).

The average share of the project at the total projects portfolio of each agency in Poland (according to Table 4) are: SMM (about 14\%); Digital Strategy (about 17\%), Search Engine Optimization (about 28\%), Pay Per Click (about 25\%).

The average share of the project at the total projects portfolio of each agency in Ukraine (according to Table 11) are: SMM (about 30\%); Search Engine Optimization (about 34\%), Pay Per Click (31\%). 
Table 11. Focus Service lines of the Top 15 Social Media Marketing Agencies in Poland (Aug. 2020)

\begin{tabular}{|l|c|c|c|c|}
\hline \multirow{2}{*}{\multicolumn{1}{|c|}{ Service lines }} & Poland & Ukraine & Poland & Ukraine \\
\cline { 2 - 5 } & \multicolumn{2}{|c|}{$\begin{array}{c}\text { Agencies share at the total } \\
\text { numbers of the agencies \% }\end{array}$} & $\begin{array}{c}\text { The average share of the project at } \\
\text { the total projects portfolio of each } \\
\text { agency, \% }\end{array}$ \\
\hline Marketing Strategy & 6,67 & - & 20 & - \\
\hline Digital Strategy & 60,0 & 40,0 & 17,7 & 16,0 \\
\hline $\begin{array}{l}\text { Search Engine } \\
\text { Optimization }\end{array}$ & 60,0 & 66,7 & 28,12 & 34,5 \\
\hline Social Media Marketing & 100 & 100 & 14,53 & 30,66 \\
\hline Conversion Optimization & 20,0 & 13,3 & 13,3 & 5,0 \\
\hline Pay Per Click & 60,0 & 66,7 & 25,5 & 31,6 \\
\hline Mobile and App Marketing & 33,4 & 20,0 & 15,0 & 20,0 \\
\hline Content Marketing & 33,4 & 33,3 & 13,0 & 10,0 \\
\hline
\end{tabular}

Developed based on: the analytics of clutch.co - Top Poland Social Media Consultants.

Today, Facebook is the most popular social network in Poland, Ukraine and the world. Facebook is an ideal place for marketing in both the B2B and B2C segments. Business pages and thematic groups are the main tool of Social Media Marketing on Facebook. Note that the most popular methods of promotion on Facebook today are: commercial, targeted, advertising and viral posts, as well as targeted advertising (only for the target audience).

Another successful social network is Instagram. SMM on the Instagram platform today is one of the most effective methods that really shapes sales and brand promotions. The main benefits of promotion on Instagram have been and remain: recognition, loyalty, reputation management and feedback.

LinkedIn is the most convenient platform for marketing campaigns. The rule works in this network: the more useful information the user uploads to his profile, the more effective the use of the network will be. LinkedIn can promote personal sales, the B2B segment, products and services designed for a narrow target audience, and products and services in the high price segment. LinkedIn promotion tools are: the company's own page; personal messages; thematic groups.

SMM-promotion also actively uses the Twitter messaging platform - the highest generator of traffic to the main site, because the "tweets" (posts) in it are short, and the user reads complete information directly from the main resource. With the help of Twitter there is a constant communication with users, informing about news, promotions and special offers, as well as communicating with subscribers on various aspects of the company (Shtal, Dmitriev, 2019).

Findings of such authors as Iryna Pentina and Anthony C. Koh (Pentina, Koh, 2015) show that adoption of SNM is strongly influenced by social influences from experts, competitors, and customers. These social influences affect intention to adopt this new technology both directly, and by affecting the perceptions of the technology usefulness.

The basic social media focuses of the top 15 SMM Agencies in Poland and Ukraine are: Facebook, Instagram, LinkedIn, Snapchat, Twitter, Influencer (Table 12). In Poland at the 2020 the most popular social media for advertising are: Facebook $(86,67$ among of the all 
15 agencies), Instagram (73,3\% among of the all 15 agencies), LinkedIn (66,7\% among of the all 15 agencies) and Influencer (40,0\% among of the all 15 agencies).

Table 12. Social Media Focus Top 15 Social Media Marketing Agencies in Poland and Ukraine (Aug. 2020)

\begin{tabular}{|l|c|c|c|c|}
\hline \multirow{2}{*}{ Advertising } & Poland & Ukraine & Poland & Ukraine \\
\cline { 2 - 5 } & $\begin{array}{c}\text { Agencies Share at the total numbers } \\
\text { of the agencies \% }\end{array}$ & \multicolumn{2}{c|}{$\begin{array}{c}\text { Average share of the project at } \\
\text { the total projects portfolio, \% }\end{array}$} \\
\hline Facebook & 86,67 & 66,7 & 54,5 & 38,5 \\
\hline Instagram & 73,3 & 66,7 & 22,7 & 33,5 \\
\hline LinkedIn & 66,7 & 53,3 & 17,8 & 26,87 \\
\hline Snapchat & 13,3 & 13,3 & 7,5 & 7,5 \\
\hline Twitter & 26,7 & 26,7 & 7,5 & 11,25 \\
\hline Influencer & 40,0 & 26,7 & 14,0 & 26,25 \\
\hline
\end{tabular}

Developed based on: the analytics of clutch.co -Top Poland and Top Ukraine Social Media Consultants.

The largest share of projects in Poland for advertising on the Internet are advertising campaigns on Facebook (54.5\%), Instagram (22.7\%), LinkedIn (17.8\%), Influencer $(14.0 \%)$.

In Ukraine, the following trends are observed: the share of advertising campaigns on Facebook and Instagram is $38.5 \%$ and $33.5 \%$, respectively; the share of LinkedIn and Influencer advertising campaigns is almost the same and is about $26 \%$.

Table 13. Social Media Focus Top 15 Social Media Marketing Agencies in Poland (Aug. 2020)

\begin{tabular}{|c|c|c|c|c|c|c|c|c|}
\hline \multirow{2}{*}{ Rank } & \multirow{2}{*}{ Agencies Name } & \multicolumn{6}{|c|}{ Advertising } & \multirow{2}{*}{ Total } \\
\hline & & Facebook & Instagram & LinkedIn & Snapchat & Twitter & Influencer & \\
\hline 1 & Ladder.io & 30 & 30 & 20 & 10 & 10 & 0 & 100 \\
\hline 2 & MTA Digital & 80 & 10 & 10 & 0 & 0 & 0 & 100 \\
\hline 3 & $\begin{array}{l}\text { FROGRIOT - digital } \\
\text { studio }\end{array}$ & 34 & 33 & 33 & 0 & 0 & 0 & 100 \\
\hline 4 & Quick SEO Help & 50 & 25 & 25 & 0 & 0 & 0 & 100 \\
\hline 5 & Skalski Growth & 50 & 15 & 15 & 5 & 5 & 10 & 100 \\
\hline 6 & Zest Creations & 40 & 40 & 10 & 0 & 0 & 10 & 100 \\
\hline 7 & \begin{tabular}{|l|} 
Biuro Podrozy \\
Reklamy \\
\end{tabular} & 20 & 30 & 20 & 0 & 5 & 25 & 100 \\
\hline 8 & MU Interactive & - & - & - & - & - & - & - \\
\hline 9 & NUEKO Digital & 70 & 20 & 10 & 0 & 0 & 0 & 100 \\
\hline 10 & Urest & 40 & 40 & 15 & 0 & 0 & 5 & 100 \\
\hline 11 & $\mathrm{x} 100$. digital & 85 & 0 & 0 & 0 & 0 & 15 & 100 \\
\hline 12 & Bluerank & - & - & - & - & - & - & - \\
\hline 13 & Strategiczni.pl & 80 & 20 & 0 & 0 & 0 & 0 & 100 \\
\hline 14 & Tribe47 & 30 & 20 & 20 & 0 & 10 & 20 & 100 \\
\hline 15 & 9BITS & 100 & 0 & 0 & 0 & 0 & 0 & 100 \\
\hline
\end{tabular}

Created by the authors based on the analytics of clutch.co - Top Poland Social Media Consultants. 
Relevant data on the analyzed Top 15 Social Media Marketing Agencies in Poland and Ukraine are presented in Table 13, 14.

These data show that the least popular, both in Poland and in Ukraine are Snapchat and Twitter (Table 13, 14).

Table 14. Social Media Focus Top 15 Social Media Marketing Agencies in Ukraine (Aug. 2020)

\begin{tabular}{|c|c|c|c|c|c|c|c|c|}
\hline \multirow{2}{*}{ Rank } & \multirow{2}{*}{ Agencies Name } & \multicolumn{6}{|c|}{\begin{tabular}{|c|} 
Advertising \\
\end{tabular}} & \multirow{2}{*}{ Total } \\
\hline & & Facebook & Instagram & LinkedIn & Snapchat & \begin{tabular}{|l|} 
Twitter \\
\end{tabular} & Influencer & \\
\hline 1 & AdTribe & 50 & 50 & 0 & 0 & \begin{tabular}{|l|l|}
0 & \\
\end{tabular} & 0 & 100 \\
\hline 2 & Respect.Studio & 0 & 0 & 100 & 0 & 0 & 0 & 100 \\
\hline 3 & Livepage & 60 & 25 & 10 & 0 & 5 & 0 & 100 \\
\hline 4 & 711media & - & - & - & - & - & - & - \\
\hline 5 & UAATEAM & 30 & 30 & 10 & 10 & 0 & 20 & 100 \\
\hline 6 & WiserBrand & 35 & 35 & 30 & 0 & 0 & 0 & 100 \\
\hline 7 & NOWEDO & - & - & - & - & - & - & - \\
\hline 8 & Mobihunter & 30 & 20 & 0 & 0 & 0 & 50 & 100 \\
\hline 9 & Kosmiqs LLC & 25 & 30 & 15 & 5 & 5 & 20 & 100 \\
\hline 10 & Areanda & 40 & 30 & 15 & 0 & 15 & 0 & 100 \\
\hline 11 & $\begin{array}{l}\text { Upturn Digital } \\
\text { Agency }\end{array}$ & - & - & - & - & - & - & - \\
\hline 12 & MixDigital & 45 & 40 & 15 & 0 & 0 & 0 & 100 \\
\hline 13 & Polimentor & - & - & - & - & - & - & - \\
\hline 14 & $\begin{array}{l}\text { Devenup Health, } \\
\text { LLC }\end{array}$ & 20 & 25 & 20 & 0 & 20 & 15 & 100 \\
\hline 15 & ITForce & 50 & 50 & 0 & 0 & 0 & 0 & 100 \\
\hline
\end{tabular}

Developed based on: the analytics of clutch.co - Top Ukraine Social Media Consultants.

The results of the study revealed that customers' loyalty to the brand is positively affected when the brand offers: advantageous campaigns, relevant content, popular contents, applications on social media, and appears on various platforms. Customers prefer to share music, technological-related, and funny contents on social media platforms (Zabadi, Abdelrahim, 2019).

Table 15. PPC Focus Top 15 Social Media Marketing Agencies in Poland and Ukraine (Aug. 2020)

\begin{tabular}{|c|c|c|c|c|}
\hline Advertising & Poland & Ukraine & Poland & Ukraine \\
\hline & \multicolumn{2}{|c|}{$\begin{array}{c}\text { Agencies Share at the total } \\
\text { numbers of the agencies \% }\end{array}$} & $\begin{array}{c}\text { Average share of the project at } \\
\text { the total projects portfolio, \% }\end{array}$ \\
\hline Google Adwords & 60,0 & 53,3 & 70,0 & 68,75 \\
\hline Amazon & 26,7 & 20,0 & 8,75 & 10,0 \\
\hline You Tube & 60,0 & 46,67 & 20,0 & 21,42 \\
\hline Bing & 26,7 & 40,0 & 10,0 & 7,5 \\
\hline Yahoo & 13,3 & 20,0 & 7,5 & 6,67 \\
\hline
\end{tabular}

Developed based on: the analytics of clutch.co - Top Poland and Ukraine Social Media Consultants. 
Analysis of PPC focus top 15 SMM agencies in Poland and Ukraine showed that the most popular is Google Adwords and You Tube (Table 15).

YouTube The world's favorite video platform doesn't share in-depth insights into its advertising audiences.

Much of this data points to the fact that music is the top draw for YouTube audiences, especially in the platform's high-growth markets. Music-related topics accounted for half of the top 20 search queries for on YouTube during 2018. Movies and 'TV content' accounted for much of the rest of the list, but it's worth noting that the games Fortnite and Minecraft both attracted huge volumes of interest on YouTube throughout 2018 (Report Global Digital Overview, 2018).

\section{SUMMARY}

SMM has many tools to influence consumer buying behavior, and the number of promotion channels surpasses all other types of marketing. The choice of promotion channel and type of SMM depends on the business goals and capabilities of the enterprise. SMM a set of activities aimed at promoting products or services of the enterprise, as well as communication with potential existing consumers on the Internet platforms of social media resources.

As we noted above, the cold, hard data show that Facebook hasn't experienced any of the dramatic user declines that the media continue to portend. In reality, Facebook user numbers continue to grow around the world, with the platform adding 18 million new users to its addressable advertising audience in Q4 of 2018 alone.

The SMM advantages are: track audience reactions in a constant mode of the present time; daily and direct contact with the target audience; great resonance in the success of the company for the relatively low cost of promotion (the desire of users to share information, distribute posts about the brand); efficiency; wide coverage of the target audience; increasing online and offline activity in social media (constant posting in the feed); use of targeted advertising; ability to use non-standard interactive formats (e.g. wiki markup); event marketing.

Using collected data, we could make the grounded choice of location of the system of artificially intelligence self-education system with the purpose of addressing social and commercial valuable information, such as, for example, advertising of the study of our University among the future students.

\section{REFERENCES}

Akram, W., Kumar, R. (2017). A Study on Positive and Negative Effects of Social Media on Society. "International Journal of Computer Sciences and Engineering”, 5(10). DOI: 10.32983/2222-4459-2019-12-446-452.

Erdoğmuş, İ.E., Çiçek, M. (2012). The Impact of Social Media Marketing on Brand Loyalty. "Procedia - Social and Behavioral Sciences", Vol. 58. DOI: 10.1016/j.sbspro.2012.09.1119.

Kemp, S. (2014). Report Global Digital Overview, 2014. Access on the internet: https://datareportal.com/reports/digital-2014-global-digital-overview.

Kemp, S. (2015). Report Global Digital Overview, 2015. Access on the internet: https://datareportal.com/reports/digital-2015-global-digital-overview.

Kemp, S. (2016). Report Global Digital Overview, 2016. Access on the internet: https://datareportal.com/reports/digital-2016-global-digital-overview. 
Kemp, S. (2017). Report Global Digital Overview, 2017. Access on the internet: https://datareportal.com/reports/digital-2017-global-digital-overview.

Kemp, S. (2018). Report Global Digital Overview, 2018. Access on the internet: https://datareportal.com/reports/digital-2018-global-digital-overview.

Kemp, S. (2019). Report Global Digital Overview, 2019. Access on the internet: https://datareportal.com/reports/digital-2019-global-digital-overview.

Kemp, S. (2020). Report Global Digital Overview, 2020. Access on the internet: https://datareportal.com/reports/digital-2020-global-digital-overview.

Miroshnik, M.V., Kopitsa, D.A., Stryuk, L.A. (2020). Digital marketing as an environment for interactive digital advertising technologies. "Business Inform”, No. 5. Access on the internet: https://doi.org/10.32983/2222-4459-2020-5-503-510.

Nitsenko, V., Chukurna, O., Mardani, A., Streimikis, J., Gerasymchuk, N., Golubkova, I., Levinska, T. (2019). Pricing in the Concept of Cognitive Marketing in the Context of Globalization: Theoretical, Methodological and Applied Aspects. "Montenegrin Journal of Economics", Vol. 15, No. 4.

Pentina, I., Koh, A. (2015). Exploring Social Media Marketing Strategies in SMEs [In:] Robinson, Jr. L. (eds). Marketing Dynamism \& Sustainability: Things Change, Things Stay the Same.... Developments in Marketing Science: Proceedings of the Academy of Marketing Science. Springer, Cham. Access on the internet: https://doi.org/10.1007/978-3-319-10912$1 \_156$.

Pysarenko, V., Dorohan-Pysarenko, L., Kantsedal, N. (2019). Application of new data formats for electronic document management in government bodies. IOP Conference Series: Materials Science and Engineering, 568(1), 012102

Report Digital 2017, Poland. Access on the internet: https://datareportal.com/reports/digital2017-poland.

Report Digital 2017, Ukraine. Access on the internet: https://datareportal.com/reports/digital2017-ukraine.

Report Digital 2018, Poland. Access on the internet: https://datareportal.com/reports/digital2018-poland.

Report Digital 2018, Ukraine. Access on the internet: https://datareportal.com/reports/digital2018-ukraine.

Report Digital 2019, Poland. Access on the internet: https://datareportal.com/reports/digital2019-poland.

Report Digital 2019, Ukraine. Access on the internet: https://datareportal.com/reports/digital2019-ukraine.

Report Digital 2020, Poland. Access on the internet: https://datareportal.com/reports/digital2020-poland.

Report Digital 2020, Ukraine. Access on the internet: https://datareportal.com/reports/digital2020-ukraine.

Shtal, T.V., Dmitriev, G.B. (2019). SMM as modern marketing technologies. "Business Inform”, No. 12.

Stecko, J. (2018). The ethical aspects of corporate social responsibility [w:] Alipoor, A., Vakili, V., eds., The International Scientific Conference on Challenges in Social Sciences and Business: Conferences Proceedings, Dubai: Pelk Publication.

Top Poland Social Media Consultants (Dec. 2020). Access on the internet: https://clutch.co/pl/agencies/social-media-marketing/leaders-matrix. 
Top Ukraine Social Media Consultants (Dec. 2020). Access on the internet: https://clutch.co/ ua/agencies/social-media-marketing/leaders-matrix.

Zabadi, A. (2019). Effect of Social Media Marketing (SMM) on Consumer's loyalty to the brand. Access on the internet: https://www.researchgate.net/publication/330834295_Effect_of_Social_ Media_Marketing_SMM_on_Consumer's_loyalty_to_the_brand.

Zatwarnicka-Madura, B., Stecko, J., Mentel, G. (2016). Brand image vs. Consumer trust. "Actual Problems of Economics", 8(182).

DOI: $10.7862 / \mathrm{rz} .2020 . \mathrm{mmr} .28$

The text was submitted to the editorial office: December 2020.

The text was accepted for publication: December 2020. 
